\title{
Real Time Investments with Adequate Portfolio Theory
}

\author{
Alina Kvietkauskienè
}

\section{A B S T R A C T}

Objective: The objective of this paper is to identify investment decision making schemes using the adequate portfolio model. This approach can be employed to project investment in stocks, using the opportunities offered by the markets and investor intelligence.

Research Design \& Methods: It was decided to use adequate portfolio theory for investment decision making, simulation of financial markets, and optimisation of utility function.

Findings: In order to achieve better performance of sustainable returns in equity portfolio, different markets, and existing companies' equities and portfolios were selected, investigating their returns based on adequate portfolio theory.

Implications \& Recommendations: The main conclusion of article suggests investigating return on individual portfolio level. Real investment is a way to make sure of the soundness of applicable strategies.

Contribution \& Value Added: The portfolios were formed from stocks of USA, German and French markets and quoted, using adequate investment portfolio system, in DNB Trade demo version, what allows monitoring of the long-term investment experiment.
Article type: research paper
Keywords:
investments; adequate portfolio; Markowitz theory; utility function; uncertainty

JEL codes:

G11, G17

Received: 20 September $2014 \quad$ Revised: 7 November $2014 \quad$ Accepted: 2 December 2014

\section{Suggested citation:}

Kvietkauskienè, A. (2014). Real Time Investments with Adequate Portfolio Theory. Entrepreneurial Business and Economics Review, 2(4), 85-100, DOI: http://dx.doi.org/10.15678/EBER.2014.020406. 


\section{INTRODUCTION}

The term "investment" is derived from the Latin word investire, which means to put. Investment means capital injection in order for its increase in the future (Cibulskienè \& Butkus, 2009).

Investing in the broad sense - is a process, which goal is to preserve and enhance the capital, monetary or other value of the funds (Rutkauskas \& Martinkutè, 2007).

Nowadays, investing should not be seen as free allocation of funds for future problems solving but the accumulation, acquisition or rational use of necessary quantity. According to Eurostat data, Lithuania is the country, which reaches the lowest return on investment in European Union practically in all investment areas. It is a focused and important economic problem effecting changes in the country's development challenges. There is a need to ensure a sustainable return on investment and develop conceptual approaches for investment in global financial markets.

The main objective of the paper is to identify investment decision making schemes using adequate portfolio model. Through this approach we can project investment in stocks, using the opportunities offered by the markets and investor intelligence.

The main objective of the article requires investigating return on individual portfolio level. Real investment is a way to assure the soundness of applicable strategies. The portfolios were formed from stocks of USA, German and French markets and quoted, using adequate investment portfolio system, in DNB Trade demo version.

The methods of inquiry are based on: the analysis of primary sources data, the study of secondary data and scientific literature, simulation of financial markets, optimisation of utility function, adequate portfolio technique.

\section{LITERATURE REVIEW}

Uncertainty exists in almost all financial markets, thus the formations of investment portfolios are based on modern economic models. One of them is Markowitz model.

Markowitz model was developed in 1952. Modern portfolio theory is based on this model. Until then, although investors understood the concept of risk, there were no measurements for risk. The scientists first suggested the maturity of effectiveness; in order to analyse a set of efficient portfolios, it is necessary to calculate the portfolio expected return and standard deviation of financial instruments. Markowitz quantified how diversification of the portfolio can reduce portfolio risk. The model is based on the expected return of stocks and risk (Valentinavičius, 2010).

Markowitz's theory is based on several assumptions:

- investors look at every investment opportunity as to probability distribution for the expected return on investment for a given period;

- investors seek to maximise the expected benefits for the investment period, and their utility curves show decreasing marginal profitability;

- investors measure portfolio risk as variation of expected return;

- investors make decisions based only on risk and return, so their utility curves are the function of expected return and the standard deviation of expected return; 
- at the same level of risk, investors prefer portfolio with higher returns, and under a fixed rate of return, investors will prefer lower risk (Reilly \& Brown, 2003).

In order to establish the efficiency of investment portfolio it is necessary to calculate the expected return and standard deviation of profitability for every portfolio. The formation of Markowitz model requires the following data:

- expected profitability of stocks;

- the standard deviation of the profitability, which measures the risk of each stocks;

- the covariance - a measure of equity profitability ratio (Kancerevyčius, 2009).

Expected profitability of portfolio is calculated as the weighted average of separate instruments' expected profitabilities:

$$
E R_{p}=\sum_{i=1}^{d} W_{i} E R_{i}
$$

where:

$E R_{p}$ - expected portfolio profitability,

$W_{i}$ - part of invested funds for instrument $i$,

$E R_{i}-$ expected profitability of instrument $i$,

$d$ - the number of instruments in the portfolio.

The foundation of modern Markowitz portfolio theory is the investor's intention to enable greater return on financial instruments for a given level of tolerated risk. This way, he/she is trying to optimise his/her own investment at the same time and his/her financial toolbox (Markowitz, 2014).

The essence of Markowitz's theory is that creating the optimal portfolio, it is necessary to take into account the volatility of stock returns while the variance or covariance can be used to assess these factors quantitatively (Valentinavičius, 2010).

Markowitz model does not impose the sole optimal portfolio; it defines the effective threshold, where all portfolios are optimal. These combinations are possible, but not necessarily correct (Markowitz, 1952; 1956). In order to determine the optimal portfolio, it uses indifference curves. These curves represent investors' attitude to risk and profitability. The higher curve represents a more desirable situation. The task of every investor is to find the portfolio tangent under the best (highest) indifference curve (Figure 1).

The point, where the efficiency limit is tangent of the indifference curve, represents an efficient portfolio of financial instruments.

The application of Markowitz's portfolio theory related to a number of restrictions, for which it is absolutely impossible to form an efficient portfolio for the following four reasons (Valentinavičius, 2010):

- The usage of past data. The calculations of expected profitability and risk are based on existing information. Composed portfolio today, may be inefficient tomorrow, because it depends on the performance of companies, investment environment, the sentiment of market participants, and many other factors.

- Changes in proportions. Changing prices of financial instruments and the proportions of portfolios, requires for the calculation of effective limits to use average rates. 
- Liquidity of financial instruments. Liquid financial instruments, due to their price fluctuations can "lift" the effective limit of above, although often it is not possible to include them in portfolio precisely because of their lack of demand and supply.

- The historical period. In order to accurately assess the effectiveness of the portfolio long-term historical data should be used, such as three years.

Markowitz developed a portfolio construction model to achieve the maximum return for a given level of risk or the minimum risk for a given level of return (Markowitz, 1952, 1956, 1959, 1987). It has long been noted that investors should diversify internationally rather than domestically and the number of securities is much larger than the U.S. market's securities (Deng \& Min, 2013).

To better extend the portfolio construction methodology and techniques on U.S. market to the international market, Guerard et al. $(2012 ; 2014)$ briefly review the applied U.S. and "Global equity investment research". These authors test whether a meanvariance optimisation technique, using the portfolio variance as the relevant risk measure, dominates the risk-return trade-off curve.

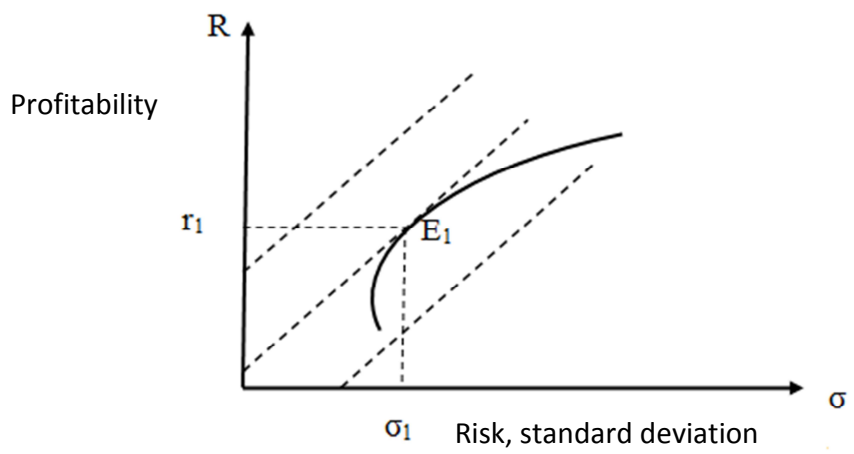

Figure 1. Effective limit and the indifference curves Source: Leipus \& Norvaiša (2003).

The expected return of portfolio is counted as separate instruments expected weighed average profitability. Meanwhile, the portfolio risk is calculated by two indicators covariance and correlation. Although the model estimates the profitability and risk, it does not impose the optimal portfolio for the investor. Using historical simulation, Markowitz and many other scientists use the arithmetic average of return in order to determine the expected profitability.

However, the average may not reflect the actual expected return on financial instrument due to presence of uncertainty in financial markets and cyclical fluctuations. In the opinion of the author, there is not enough approaches for finding a constructive investment decision. Therefore, the author uses the adequate portfolio model for market selection and investment decisions (section 3). 


\section{MATERIAL AND METHODS}

The above briefly discussed investment portfolios have become the classic works at investment decisions management. New knowledge is built and new problems are formulated by studying them. In author's opinion, in many investment situations it is necessary to evaluate all the possibilities for investor in order to choose the best.

Formation and management of portfolio requires effective evaluation of various portfolio conditions existing on the efficiency curve, description of their interaction, and analysis of other portfolio characteristics. Portfolio decisions should be achieved when it is impossible to describe the profit possibilities of portfolio as point estimated, but as their distribution of probability (Rutkauskas, 2000).

Before examining the concept of adequate portfolio, it should be understood that this is a common set of financial assets that determine the reliability of profitability. The idea of this portfolio first was proposed by Rutkauskas (2000), in the following works he examined the specific features of this theory (Rutkauskas, 2001, 2005a, 2005b, 2006, Rutkauskas et al., 2009; Rutkauskas \& Kvietkauskienè, 2013b). The essence of this theory is assessment of investment portfolio risk, profitability and reliability.

The guidelines of modern portfolio theory is not clearly adaptable in practice, since, as mentioned earlier, not all of the investment portfolio owners can quantify their utility curve as the measure of profitability and risk unification.

In terms of the profitability of investment portfolio and its measurement, the concept of average return is one of the solutions feasibilities, but not the most accurate, not the only one. The average of arithmetic profitability - is a generalised status of potential portfolio return for all investments. In each particular case, the average profit will be one of the profit opportunities that fully describe only their probability distribution. The alternative to this approach offers Rutkauskas (2000), as the average portfolio return is the calculation method that gives a way to the quintile or percentile performance.

The examination of adequate portfolio theory is a common set of financial assets, for reliability of profitability determination. Analysed investment portfolio process allows extending the opportunities of Markowitz modern portfolio, because, in author's understanding, the adequate portfolio is a natural extension of Markowitz portfolio. One of the main advantages of investment decisions is assessment of reliability. Standard deviation is widespread among investigators and is not an appropriate tool to describe the objectives of investor. It is important not only investment riskiness, but the attention must be given to the reliability of each option (Rutkauskas, 2000). The effective decisions of modern investment portfolio become the starting point for adequate investment decisions. The propinquity of modern and adequate portfolio is illustrated through effective and maximum areas, as well as three-dimensional utility function of finding the most advantageous portfolio for the investor.

Knowing the parameters of profitability and risk, it is possible to determine the effective limit of portfolio, where the rational investor should choose the portfolio. The limit of efficiency shows the composition of the portfolio combinations that give the highest return for a given risk, and, similarly, those portfolios have the lowest risk for a given level of return. 
In order to establish an effective portfolio limit (in case of more than two securities), the process should start from the identification of portfolio set. All the possible combinations of portfolio risk and return presented graphically establish the potential portfolio field.

The concept of adequate portfolio enables the identification for investment portfolio holder the overall profitability of active possibilities, thus simplifies the decision-making path. It would be appropriate to compare the classical and adequate portfolio models (Table 1).

Table 1. The comparison of classical and adequate portfolio

\begin{tabular}{|l|l|}
\hline \multicolumn{1}{|c|}{ Classical portfolio theory } & \multicolumn{1}{|c|}{ Adequate portfolio theory } \\
\hline $\begin{array}{l}\text { Determines the efficiency line, where existing } \\
\text { portfolios possess expected (average) } \\
\text { profitability among given portfolios of } \\
\text { riskiness. }\end{array}$ & $\begin{array}{l}\text { Determines the efficiency zone, where level } \\
\text { of possible portfolio risk possesses the } \\
\text { distribution of maximum possibility } \\
\text { profitability. }\end{array}$ \\
\hline $\begin{array}{l}\text { The indifference curve of investor allows to } \\
\text { choose a portfolio structure, where investor } \\
\text { will be able to gain the maximum of average } \\
\text { profitability. }\end{array}$ & $\begin{array}{l}\text { Utility function of investor can experience the } \\
\text { level of risk and the highest possibilities } \\
\text { distribution that maximise the investor's } \\
\text { benefit. }\end{array}$ \\
\hline $\begin{array}{l}\text { The choice of investment and portfolio } \\
\text { investment is made in the interaction } \\
\text { between average profitability and riskiness of } \\
\text { profitability possibilities (often - standard } \\
\text { deviation) trends that take into account } \\
\text { investor's indifference curve of average } \\
\text { profit. }\end{array}$ & $\begin{array}{l}\text { Profitability possibilities of investment } \\
\text { portfolio are examined together with } \\
\text { recipient of risk ant utility function, which } \\
\text { takes into account the possibilities probability } \\
\text { distributions. }\end{array}$ \\
\hline
\end{tabular}

Source: own elaboration based on Rutkauskas (2000; 2005a).

In order to understand the guidelines of adequate portfolio theory it is necessary to analyse the geometric image of investment portfolio. The choice of investor should be moved into a three-dimensional plane where the portfolio risk is deferred in abscissa, portfolio profitability possibilities - in ordinate, and the third characteristic - the portfolio profitability reliability - in applicate (Rutkauskas, 2000). This three-dimensional surface view is called the efficiency zone that is made up of all quintile effective lines (Rutkauskas \& Stankevičienè, 2003). According to the adequate theory model, the investor will seek to maximise the guarantee that the profitability will be no less than the selected level. The set of effective lines is defined as izoguarantee of investment portfolio - the line of opportunities surface, connecting points of equal guarantees. If probability of all izoguarantee portfolio value at not less than changing value, the investor should choose the maximum of the probability possibility (Rutkauskas, 2003).

If the set of possibilities of Markowitz portfolio (Figure 2 top row) generates an effective line, where the possibilities of optimal solution concentrate and each of them, these situations are described as possibilities of average profitability and riskiness. Then the bunch of possibilities for adequate portfolio generates the bunch of effective lines (Figure 2 bottom row). 


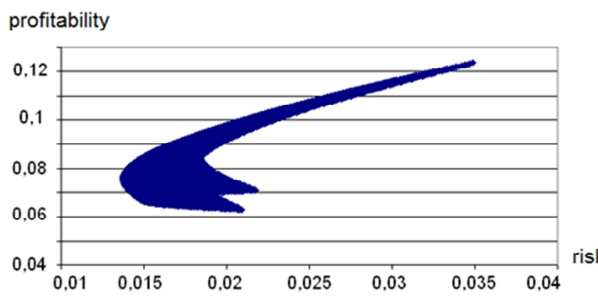

a) Markovitz "mean - standard deviation set of portfolio values

profitability

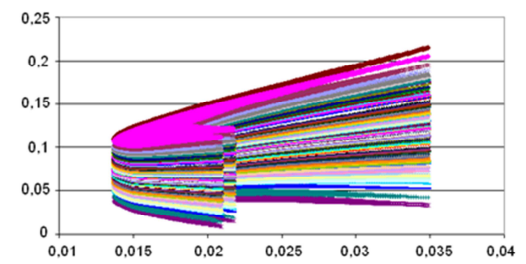

c) The set of "percentiles - standard deviation" portfolio values

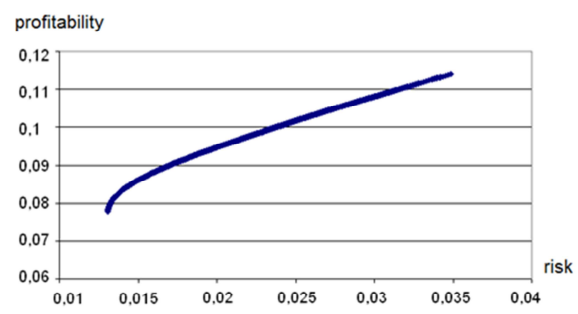

b) The efficient frontier of "mean standard deviation" portfolio set of values

profitability

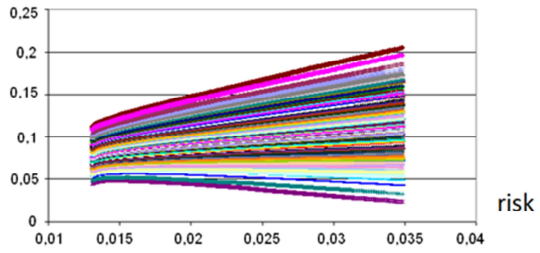

d) Efficient frontiers of the bunch of "quantiles - standard deviation" portfolios

Figure 2. Scheme of formation sets of portfolio efficient values Source: Rutkauskas et al. (2013, p. 862).

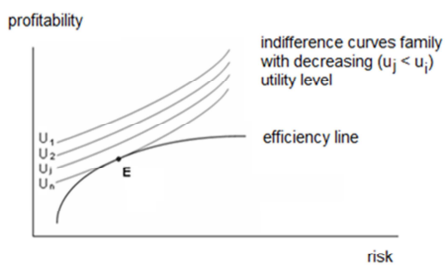

a) Tangency point $(E)$ of indifference curves family and efficient frontier - the optimal portfolio for the investor in profitability - risk plane

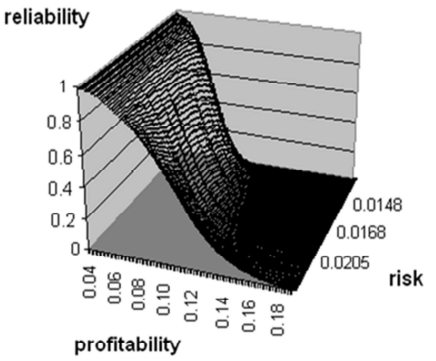

b) Efficient surface (geometrical view) of adequate portfolio

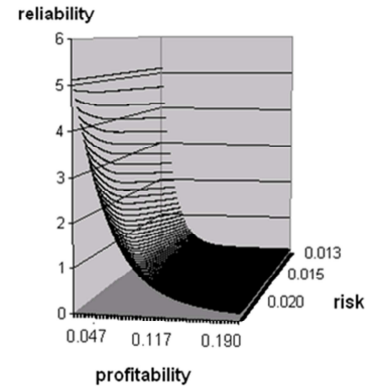

c) The view of utility function

Figure 3. Possibilities' surface of adequate portfolio and investor's utility function Source: Rutkauskas et al. (2013, p. 863). 
As shown below (Figure 3), if the optimal solution in Markowitz portfolio is indicated by tangency of efficiency line and utility curve (bottom row in Figure 3), the optimal solution is found in adequate portfolio by tangency of return surface with surface utility function.

The view of three-dimensional effective area especially is useful for understanding the influence of distributions of individual investments forms on overall portfolio opportunities distribution form.

\section{The Optimisation of Utility Function}

The utility function is the rule by which assignment is done and depends on the preferences of the individual decision maker. In utility theory, the utility measures of the consequences are assumed to reflect a decision maker's preferences in the following sense:

- the numerical order of utilities for consequences preserves the decision maker's preference order among the consequences;

- the numerical order of expected utilities of alternatives preserves the decision maker's preference order among these alternatives (Zavadskas \& Turskis, 2011).

In this work in order to explore and identify the opportunities, which the market offers for investors, were taken into account the impact of globalisation to financial markets. The authors (Rutkauskas \& Kvietkauskiene, 2012, 2013a) define that the rate of return on financial assets is possibilities probability distribution.

In order to effectively allocate available resources in the financial markets, it is important to identify the opportunities offered by the markets, profitability and risk level. This way markets are selected, where investors, by taking the appropriate level of risk, will receive the complex of utility and reliability (Rutkauskas et al., 2013).

In this case, in order to achieve successful investment decisions, it should appeal to the survival function, which would allow evaluating each market opportunity by the size of possibility and guarantee of this size. This scheme will enable quicker, than with all other models and methods, review of market opportunities. The choice of useful options for entity is associated with equivalent recovery of utility function.

Whereas the utility is associated with efficiency, reliability and risk, it is possible to invoke the utility function:

$$
U=\frac{f(e) \cdot f(p)}{f(r)}
$$

where:

$U-$ is utility function,

$f(e)$ - efficiency,

$f(p)$ - reliability,

$f(r)$ - riskiness.

In order to select the utility function, which is the most useful, it is necessary to take into account the profitability and reliability. Utility function depends on the efficiency and reliability, and reliability is associated with riskiness, so from the available data are calculated and plot the so-called survival function. On the basis of calculations 
and diagrams all selected capital markets can be ranked according to the investor's utility function approach.

\section{RESULTS AND DISCUSSION}

Using adequate investment portfolio system in DNB Trade demo version the stocks portfolios in USA, German and French markets were analysed. DNB Trade platform was chosen because of its functionality and the similarity of the investors operating tools in global capital and currency markets. It is easy to manage investments (buy and sell financial instruments), replicate with technical analysis indicators (graphs and their modifications) and publish required data for fundamental macro analysis and news flow. The process of transaction and the order submission is fully automated.

The author offers such model of real investment in selected appropriate financial markets (Figure 4).

Selection of companies stocks based on financial indicators - the first step, where these sectors are identified, in which investment funds mainly invest. The goal of this stage is to select stocks for chosen markets.

Selection of the companies by investment funds. The main aim of this stage - to identify sectors, where the biggest part of investment funds capital is invested.

Portfolios formation for chosen markets (50\%/50\%). The main aim of this stage is to analyse the financial indicators of selected stocks and to determine, which stocks are chosen by selected funds and which are selected by author.

Portfolios simulation with adequate portfolio theory - to perform investment decisions for coming weeks using portfolio simulation with adequate portfolio theory.

Portfolios performance comparison with index. The aim of this model stage is to compare investment results with benchmark.

Investment portfolio were formed in NASDAQ, DAX, NYSE and CAC40 markets by adequate investment portfolio system support that was discussed in theoretical and methodological part. Investments were made with selected companies' shares.

Weekly investment was chosen for several reasons:

1. In this way the cost of sales and buying is reduced.

2. It is appropriate to use a weekly investment, when active portfolio manage-ment model is used for investment.

Testing period - 2012.12.04 - 2014.10.01 (102 weeks, from which 40 weeks required for system analysis and these results are submitted in this article, and during the remaining 62 weeks active investment of simulated nature were conducted).

During the investigation, using an adequate portfolio method with week data were used $0.003(0.3 \%)$ rebalancing charges for entering or closing position. Taxes choose using the average tax rate that is used by DNB Trade platform.

Created portfolios were managed using a program of simulations, which evaluate the profitability of assets, risk and profitability reliability. The short description of investment strategy:

- a separate stock portfolio was formed in every financial market. Every portfolio was formed from six shares;

- initial every portfolio amount - 100000 EUR; 
- the purpose of portfolio - to reach as far as possible a sustainable return on investment, i.e. return closely to or above the benchmark over the long period;

- investment decisions were performed for coming week, after week portfolio is reviewed and, if necessary, reformed.

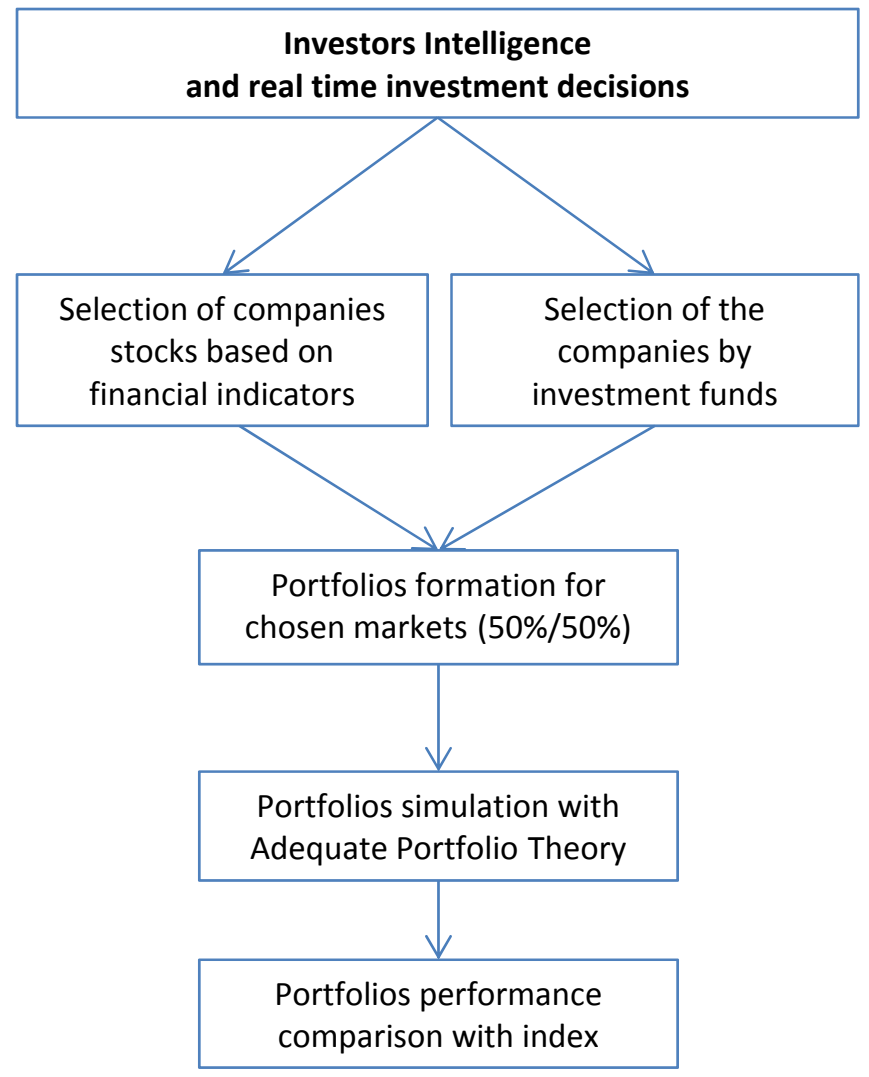

Figure 4. Investment decision-making model Source: own elaboration.

Four portfolios formed 2012-12-04 and managed until 2014-10-01. As the experiment, the least diversified portfolio was composed for USA (NASDAQ) market. Only companies from technology sector were selected for this portfolio. Other portfolio for USA (NYSE) market was composed of stocks from different sectors.

The most objected thing is comparison of results and index, which is used by many experts and practitioners, because, according to comparison of results and index, we can assess the results. In order to clarify whether the portfolio has been successfully optimised, the results were compared with NYSE index (Figure 5). 


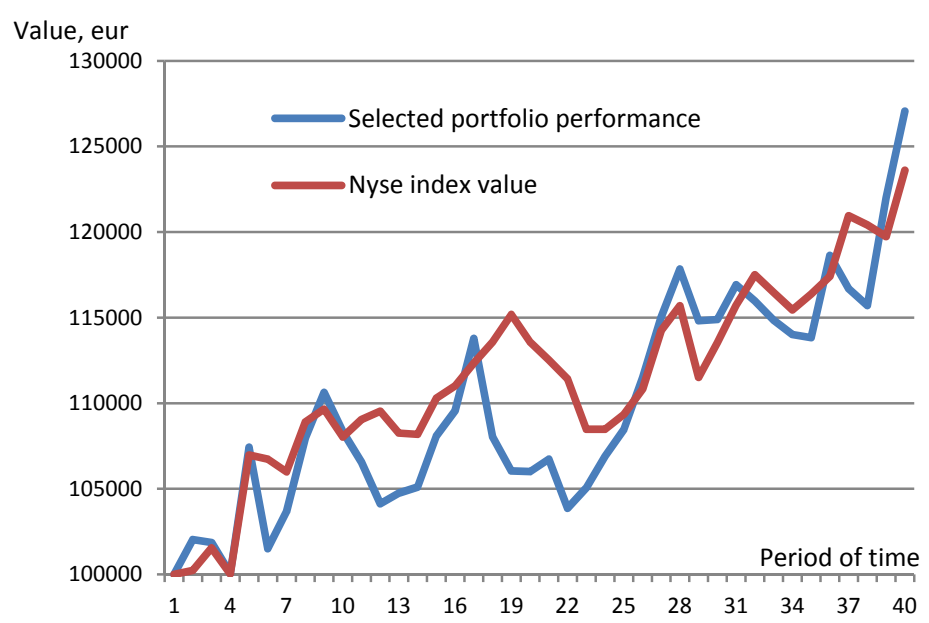

Figure 5. Comparison of portfolio and NYSE index

Source: own elaboration based on investment results.

It is seen that, based on created investment model, managed portfolio value is greater than the value of the index during the analysed period. This means that the portfolio management has been successful and the desired result was achieved. Since market is examined during conditions of globalisation, the results should be compared with the overall S\&P 500 index and benchmark (MSCI World index) (Figure 6).

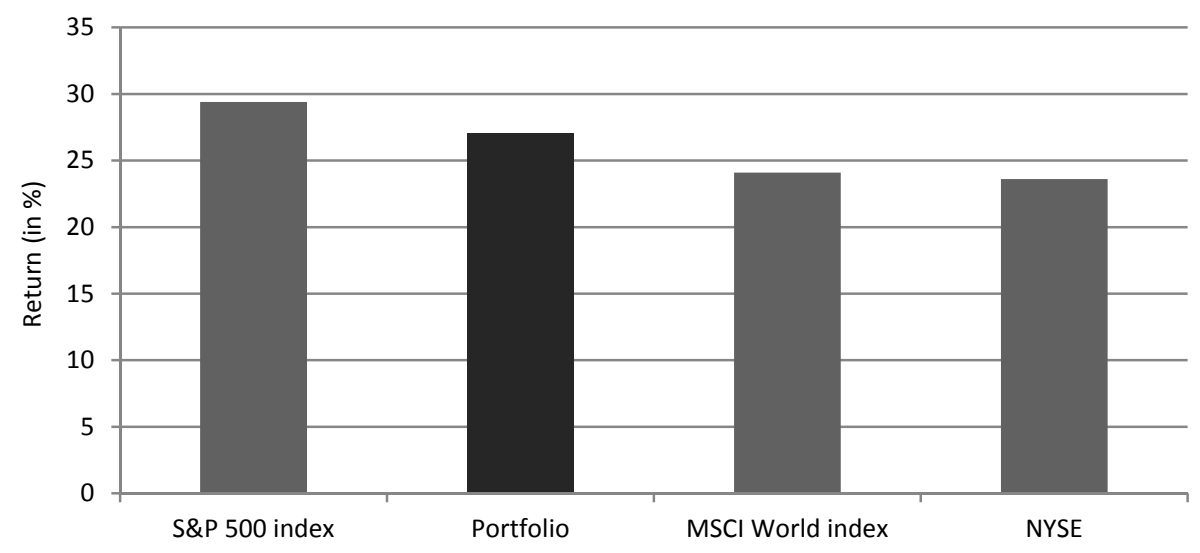

Figure 6. Comparison of portfolio and S\&P 500, MSCI World index and NYSE index Source: own elaboration based on investment results.

Only the return of S\&P 500 index exceeds the portfolio return by $2 \%$, and the result of own portfolio exceeds the $\mathrm{MSCl}$ index by $3 \%$ and NYSE index $-4 \%$. As the sustainability can be understood as return on long-term investment period, which is close to global 
index, it can be concluded that sustainable investment return has been obtained in the USA market.

It would be appropriate to compare the results of the portfolio with the USA (NASDAQ) portfolio profitability (Figure 7).

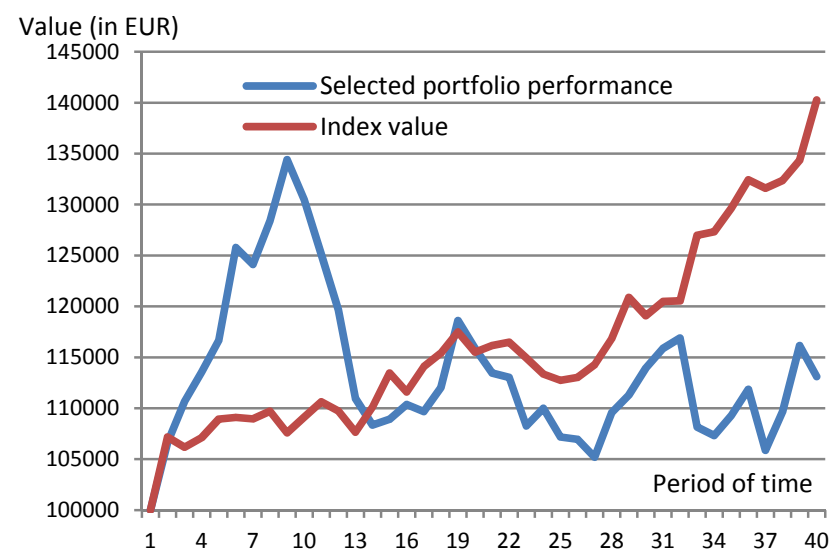

Figure 7. Comparison between portfolio and NASDAQ index Source: own elaboration based on investment results.

The profitability of this portfolio is $13.19 \%$, but the profitability of benchmark is about $40 \%$ during analysed period. This can be related to the following reasons:

- during investment period, Nasdaq market was only the analogue of sector by its specifics, because the portfolio was formatted only from stocks of technology sectors;

- higher market fluctuations were present in Nasdaq market;

- liquidity of Nasdaq market is less than the liquidity of NYSE market.

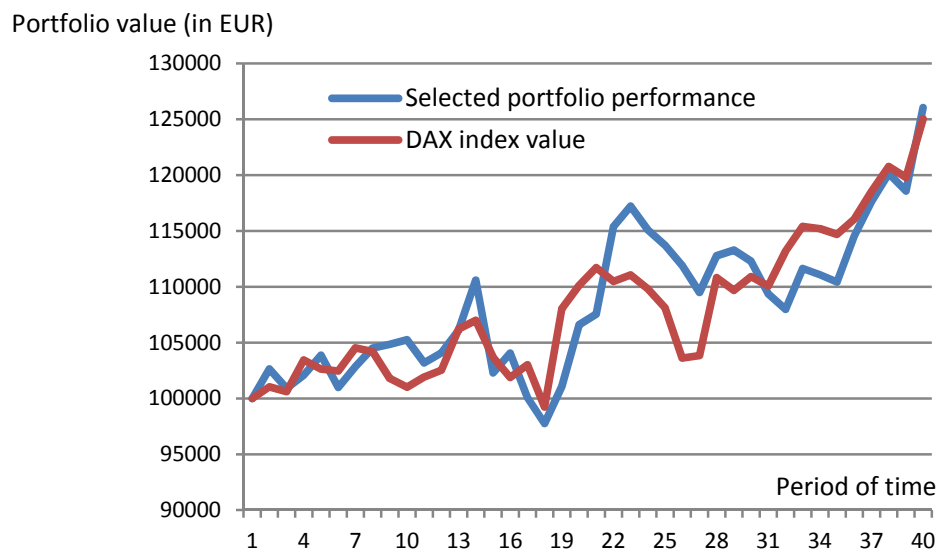

Figure 8. Comparison between portfolio and DAX index

Source: own elaboration based on investment results. 
The investments in German (DAX) market were relatively stable. As seen from obtained results, the portfolio return (after elimination all taxes) over the period is $25.05 \%$.

In order to clarify whether the portfolio has been successfully optimised, the results were compared with benchmark (DAX index) (Figure 8).

The return of benchmark is less by $1 \%$. In order to clarify whether the portfolio has been successfully optimised the MSCI Europe index, which reflects the stock market, the results of portfolio and index were selected for comparison.

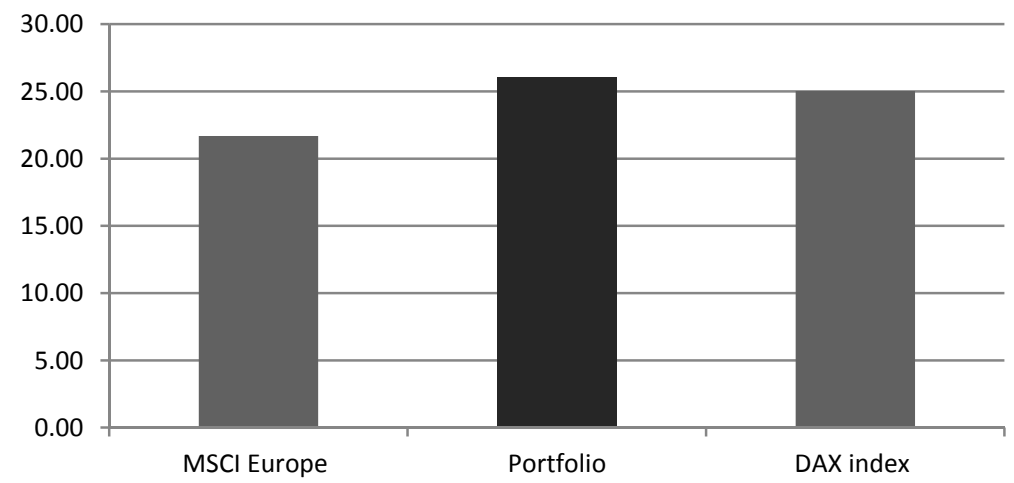

Figure 9. Comparison between portfolio and MSCl Europe Source: own elaboration based on investment results.

The portfolio return exceeds the return of $\mathrm{MSCl}$ Europe index by 4.36 percentage point (Figure 9). Investment decisions have been formed using the system of adequate portfolio model. It would be appropriate to compare the results of the German (DAX) portfolio with the profitability of French (CAC 40) portfolio (Figure 10).

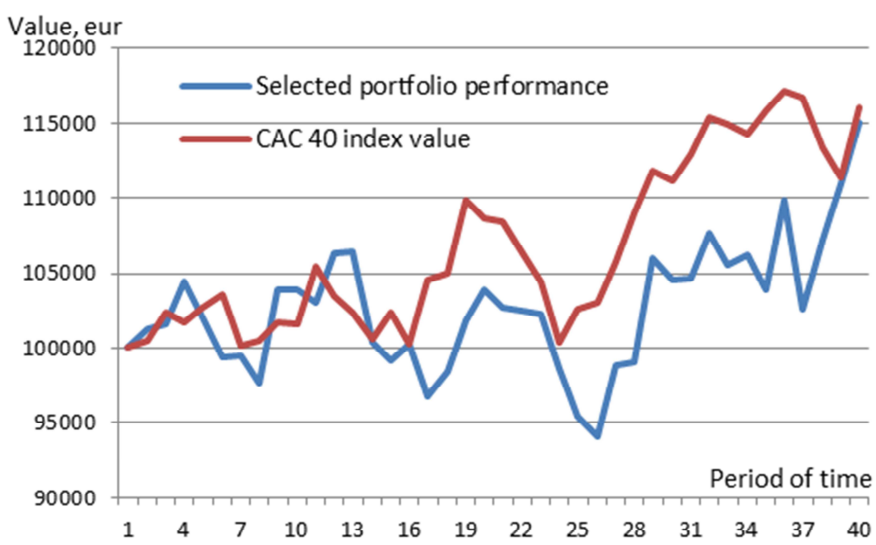

Figure 10. Comparison between portfolio and CAC 40 Index Source: own elaboration based on investment results. 
The profitability of this portfolio is $15.08 \%$, but the profitability of benchmark is about $17 \%$ during analysed investment period, so the portfolio result does not exceed benchmark. The following reasons can be distinguished:

- the French market has its own specification;

- the standard deviation of French market is higher than the standard deviation of German market, so as small as possible standard deviation means less value of the shares, and therefore smaller risk.

\section{CONCLUSIONS}

The effective decisions of modern investment portfolio become the starting point for adequate investment decisions. The propinquity of modern and adequate portfolio is illustrated through effective and maximum areas, as well as three-dimensional utility function of finding the most advantageous portfolio for the investor.

The adequate portfolio model is more suitable for investment, when stocks in portfolio are from different sectors.

The German market has been identified as the most stable and one of the most suitable markets for investors. Testing the market in real time, the results of this market were one of the best compared with the index (25.05\% return).

USA market was assessed according to profitability, efficiency and risk and other indicators were also selected for further investment. However, the USA market was divided into two separate markets at the investment stage: the NYSE and Nasdaq. The investment result in NYSE market was also one of the best (25.65\% return). The experiment was done with Nasdaq market - the structure of portfolio consisted of selected technology sector shares. Although the investment portfolio in this market generated a positive return, but it was not greater than the index returns.

Analysis of the markets allowed choosing the French market, but taking into account a risk. Risk was confirmed, the return in French market was about 15\%, but they were not higher than the index.

\section{REFERENCES}

Cibulkienè, D., \& Butkus, M. (2009). Investiciju ekonomika: finansinés investicijos: mokomoji knyga. Šiauliai: V̌̌l Šiaulių universiteto leidykla.

Deng, S., \& Min, X. (2013). Applied Optimization in global efficient portfolio construction using earnings forecasts. Journal of Investing, 22(4), 104-114.

Guerard, J.B., Markowitz, H., \& Xu, G.; Chettiappan, S. 2014. Investing in Global and Emerging Markets: An Application of Integer Programming Retrieved on September 15, 2014, from: http://forecasters.org/wp/wp-content/uploads/gravity_forms/7-2a51b93047891f1ec3608b dbd77ca58d/2014/08/GuerardMarkowitzXuChettiappan_ISF2014compliance_06212014.pdf.

Guerard, J.B., Jr., Krauklis, E., \& Kumar, M. (2012). Further analysis of efficient portfolios with the USER Model. Journal of Investing, 21(1), 81-88.

Kancerevyčius, G. (2009). Finansai ir investicijos. III atnaujintas leidimas. Kaunas: Smaltijos leidykla. Leipus, R., \& Norvaiša, R. (2003). Finansų rinkos teorijų pagrindai. Pinigu studijos 4.

Markowitz, H.M. (1952). Portfolio selection. Journal of Finance, 7(1), 77-91. 
Markowitz, H.M. (1956). The optimization of a quadratic function subject to linear constraints. Naval Research Logistics Quarterly, 3, 111-133.

Markowitz, H.M. (1959). Portfolio Selection: Efficient Diversification of Investment. Cowles Foundation Monograph 16. New York: John Wiley \& Sons.

Markowitz, H.M. (1987). Mean - Variance Analysis in Portfolio Choice and Capital Markets. Oxford: Basil Blackwell.

Markowitz, H. (2014). Mean-variance approximations to expected utility. European Journal of Opetational Research, 234(2), 346-355.

Reilly, F.K., \& Brown, K.C. (2003). Investment analysis and portfolio management. South-Western: Thomson Learning.

Rutkauskas, A.V., \& Kvietkauskienè, A. (2013a). Investment decisions in global financial markets: the experience of Lithuania. Entrepreneurial Business and Economics Review, 1(4), 21-35.

Rutkauskas, A.V., Kvietkauskienė, A. (2013b). Investment in financial markets: avoidance of risk or looking for success?, in the conference proceedings Problems of modern economy: global, national and regional context (May 23-24, 2013, Grodno, Belarus). 1-6.

Rutkauskas, A.V., Kvietkauskienè, A., \& Vyšniauskas, P. (2013). Hunting for sustainable investment return in global financial markets, The 8th international scientific conference "Business and Management 2014" : selected papers. Vilnius: Technika. Retrieved on September 15, 2014, from <http://www.bm.vgtu.It/index.php/bm/bm_2014/paper/view/315>.

Rutkauskas, A.V., \& Kvietkauskienè, A. (2012). Successful investment - market behavior and investing intelligence compatibility result, in the conference proceedings Contemporary issues in business, management and education'2012 (15 November, 2012, Vilnius, Lithuania). Retrieved on September 15, 2014, from <http://cbme.vgtu.It/index.php/cbme/cbme_2012/ schedConf/ presentations>.

Rutkauskas, A. V., Stasytytè, V., \& Borisova, J. (2009). Adequate portfolio as a conceptual model of investment profitability, risk and reliability adjustment to investors interests. Economics \& Management, 14, 1170-1174.

Rutkauskas, A.V., \& Martinkutė, R. (2007). Investiciju portfelio anatomija ir valdymas. Vilnius: Technika.

Rutkauskas, A.V. (2006). Adequate investment portfolio anatomy and decisions, applying Imitative technologies, Economics, 75, 52-76.

Rutkauskas, A.V. (2005a). Portfelio sprendimai valiutų kursų ir kapitalo rinkose. Verslas: teorija ir praktika, 6(2), 107-116.

Rutkauskas, A.V. (2005b). The double-trump decision management model in global exchange. Ekonomika: mokslo darbai, 72, 84-104.

Rutkauskas, A.V., \& Stankevičienè, J. (2003). Formation of an investment portfolio adequate for stochasticity of profit possibilities. Journal of Business Economics and Management, 4(1), 312.

Rutkauskas, A.V. (2001). Investicijų portfelis, atsižvelgiant i pelno galimybių tikimybès skirstinius pilnumoje. Ekonomika ir vadyba. Kn. 7. Finansu valdymo aktualijos: tarptautinés konferencijos pranešimu medžiaga. Kaunas: Technologija.

Rutkauskas, A.V. (2000). Formation of adequate investment portfolio for stochasticity of profit possibilities. Vilnius: Technika.

Valentinavičius S. (2010). Investicijy valdymas: teoriniai ir praktiniai aspektai: monografija. Vilnius: VU Leidykla. 
Zavadskas, E.K., \& Turskis, Z. (2011). Multiple criteria decision making (MCDM) methods in economics: an overview. Technological and Economic Development of Economy, 17(2), 397427. doi: $10.3846 / 20294913.2011 .593291$

\title{
Author
}

\begin{abstract}
Alina Kvietkauskienè
Bachelor of Business Administration (Vilnius Gediminas Technical University, Lithuania); Master in Investment Management (Vilnius Gediminas Technical University, Lithuania); PhD student in Economics (Vilnius Gediminas Technical University, Lithuania). Assistant at the Department of Finance Engineering at Vilnius Gediminas Technical University (Lithuania). Her research interests include: investment portfolio management, sustainable investment return, financial market behaviour, risk management in financial markets, sustainable development.
\end{abstract}

\section{Correspondence to:}

Alina Kvietkauskienè

Vilnius Gediminas Technical University

Faculty of Business Management

Sauletekio al. 11

10223 Vilnius, Lithuania

alina.kvietkauskiene@vgtu.It

\section{Copyright and License}

This article is published under the terms of the Creative Commons Attribution - NonCommercial - NoDerivs (CC BY-NC-ND 3.0) License http://creativecommons.org/licenses/by-nc-nd/3.0/ 